2013-10-01

\title{
Feed-in Tariff Design for Domestic Scale Grid-Connected PV Systems Using High Resolution Household Electricity Demand Data
}

\author{
Lacour Ayompe \\ Technological University Dublin, lacour.ayompe@tudublin.ie \\ Aidan Duffy \\ Technological University Dublin, aidan.duffy@tudublin.ie
}

Follow this and additional works at: https://arrow.tudublin.ie/engschcivart

Part of the Other Civil and Environmental Engineering Commons

\section{Recommended Citation}

Ayompe, L. and Duffy, A. Feed-in tariff design for domestic scale grid-connected PV systems using high resolution household electricity demand data. Energy Policy (2013): 61; 619-627. doi:10.1016/

j.enpol.2013.06.102.

This Article is brought to you for free and open access by the School of Civil and Structural Engineering at ARROW@TU Dublin. It has been accepted for inclusion in Articles by an authorized administrator of ARROW@TU Dublin. For more information, please contact arrow.admin@tudublin.ie, aisling.coyne@tudublin.ie, gerard.connolly@tudublin.ie.

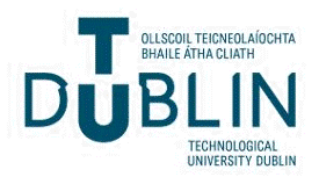




\title{
Feed-in tariff design for domestic scale grid-connected PV systems using high resolution household electricity demand data
}

\author{
L.M. Ayompe ${ }^{1}$ and A. Duffy \\ School of Civil \& Building Services Engineering and Dublin Energy Lab, Dublin \\ Institute of Technology, Dublin 1, Ireland.
}

\begin{abstract}
The advent of large samples of smart metering data allows policymakers to design Feed-in Tariffs which are more targeted and efficient. This paper presents a methodology which uses these data to design FITs for domestic scale gridconnected PV systems in Ireland. A sample of 2,551 household electricity demand data collected at $1 / 2$-hourly intervals, electricity output from a $2.82 \mathrm{~kW}_{\mathrm{p}} \mathrm{PV}$ system over the same time interval as well as PV system costs and electricity tariffs were used to determine the required FIT to make it worthwhile for the households to invest in the PV system. The methodology shows that it is possible to design single, multiple and continuous FITs. Continuous FITs are the most efficient and result in no overcompensation to the housholder while single and multiple FITs are less efficient since they result in different levels of overcompensation. In the PV case study considered, it was shown that the use of three FITs $(0.3170,0.3315$ and $0.3475 € / \mathrm{kWh}$ ) resulted in a $59.6 \%$ reduction in overcompensation compared to a single FIT of $0.3475 € / \mathrm{kWh}$; assuming immediate and complete uptake of the technology, this would result in NPV savings of over $€ 597 m$ to the Irish government over a 25 year lifetime.
\end{abstract}

Keywords: Photovoltaic system, feed-in tariff, smart meter.

${ }^{1}$ Corresponding author Tel: +353 14023940; email: lacour.ayompe@dit.ie 


\section{Introduction}

Many countries have policies which directly subsidise small-scale photovoltaic (PV) systems for domestic applications. These reduce greenhouse gas (GHG) emissions, promote energy awareness among the public and enhance security of supply, albeit at a relatively small scale compared to conventional, central electricity production technologies. A further reason for supporting homeowners and small businesses to install PV systems is to encourage them to produce part of the electricity they consume, thus reducing distributional losses and the need for network upgrades. Although the decision to invest in gridconnected PV systems at a household level is often driven by environmental concerns, most investors are interested in a favourable return on their investment. This is normally achieved through supplementary payments to the investor for electricity produced which create the cashflows necessary to make the investment worthwhile; typically this is by way of a guaranteed payment per unit of electricity produced by the PV system, normally referred to as a Feed-in Tariff (FIT). The subsidy component costs of FITs are normally spread among taxpayers and/or electricity users; it is therefore important that economic efficiency is central to their design.

Historically, two different microgeneration metering strategies have been used: gross and net metering, from which data were collected typically up to several times a year. In gross metering, the meter records the total $\mathrm{kWh}$ of electricity produced by the PV system. In net metering, the meter recording is based on the difference between the total amount of electricity produced by the PV 
system and the portion that is used on-site. When the output power from the PV system is more than that consumed on-site, the excess is exported to the grid and registered in the export meter. Recently, a third type of metering known as 'smart metering' has been introduced where both the total quantity of electricity generated, used on-site and exported are measured at small time intervals of typically less than 1 hour. Directive (2009/72/EC) of the European Commission commits member states to provide at least $80 \%$ of households with smart meters by 2020 (subject to certain conditions). The advent of smart metering allows an accurate assessment of the financial performance of household embedded generation, including PV. These three typical domestic scale grid-connected PV system metering configurations (gross metering; net metering; and smart metering) are shown in Fig. 1.

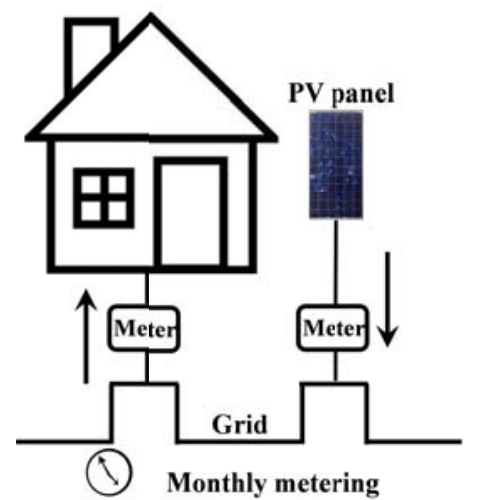

Gross Metering

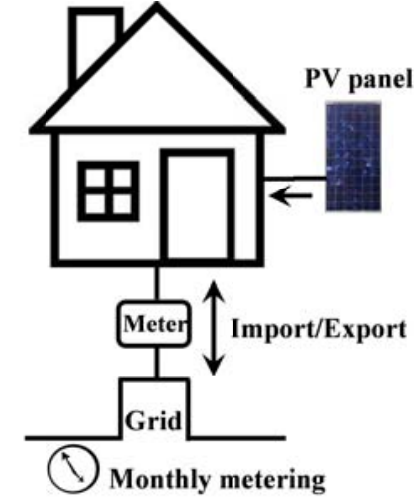

Net Metering

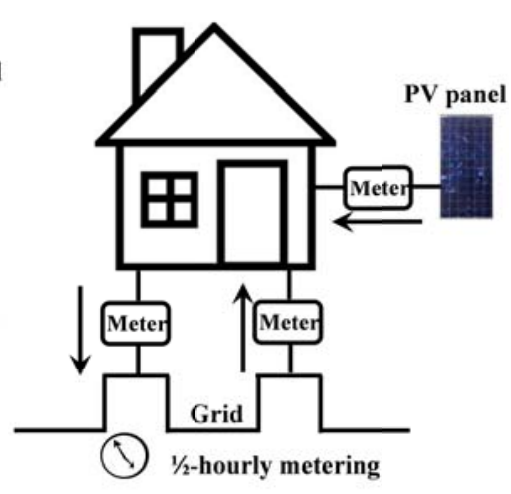

Smart Metering

Fig. 1. Typical domestic scale grid-connected PV system metering configurations

The approaches to designing FITs for the different metering configurations vary. FIT design for a gross metering configuration is simple since annual yields are 
predictable and can be used to directly determine the tariff required to meet the capital outlay. However, FIT design for modern metering methods such as smart metering must take into account the instantaneous quantities of electricity generated by the PV system, electricity used on-site as well as that exported to the grid. The same PV system will perform differently (both in terms of energy balance and financially) depending on the electricity demand profile of the dwelling. For this reason, and because of the small time-steps involved, FITs for smart-metered dwellings can be more complicated to design, but are more efficient than conventional approaches based on monthly or annual data.

FITs for domestic PV systems tend to target the 1-4 kW $\mathrm{k}_{\mathrm{p}}$ range (e.g. UK, Italy, Portugal) and normally a single, fixed tariff is offered by the energy supplier (e.g. Germany, Spain, Greece, Italy). In the UK where smart metering exists, such tariffs are normally designed based on an assumed ratio of a 50:50 split between on-site consumption and spill due to the absence of high resolution electricity demand data (Department of Energy and Climate Change, 2010). However, new high time resolution household electricity demand data from smart meters can be matched to dynamic PV outputs to determine the precise quantity of electricity consumed on-site as well as that exported to the grid. This information can be used to design more accurate FITs for different user categories, or even individual users.

It can be seen from the foregoing that the design of FITs is a complex process involving many variables such as PV system size and cost, electricity generation cost and tariffs or the desired proportion of on-site consumption. However, with the advent of smart metering data in different countries and validated dynamic models for PV electricity output (Mondol et al., 2007; Ayompe et 
al., 2010; Huld et al., 2011), it is now possible to accurately design PV FITs even to the level of an individual dwelling, prior to the purchase and installation of any system. Such knowledge can be extended to calculate marginal abatement costs and the benefit-cost balances to society. Therefore the aim of this paper is to present a new methodology for FIT design for domestic scale grid-connected PV systems using high resolution smart metered household electricity demand data, simulated PV system power outputs as well as capital cost survey data and electricity tariffs. The methodology is demonstrated using Irish data.

\section{Feed-in Tariff}

A feed-in tariff (FIT) refers to an explicit monetary reward for producing electricity using renewable energy technologies (RETs), at a rate per $\mathrm{kWh}$. It has been used for a variety of RETs, most notably wind power, but is also used for microgeneration technologies such as PV. Typically, FIT schemes involve an obligation on the part of a utilities company to purchase any electricity produced by renewable energy producers in their service area at a tariff determined by the public authorities and guaranteed for a specified period of time (Menanteau et al., 2003). These periods are usually long, covering a significant portion of the working life of the installation (Candelise et al., 2010). Long-term tariff structures are needed so that an investor can obtain a return on investment without substantial risk and because RETs are typically capital-intensive with long pay-back periods.

The value of an FIT is usually determined based on the technology used and the size of installation to account for technology and scale cost factors. For example, FITs for onshore wind typically range from $0.05 € / \mathrm{kWh}$ to $0.12 € / \mathrm{kWh}$ 
while an FIT as high as $0.50 € / \mathrm{kWh}$ is not unusual for PV investments (European Commission, 2012).

Advocates of FITs (Mitchell et al., 2006; David, 2007) argue that they are the most cost-effective means of producing rapid deployment of RETs for electricity generation at the least cost. Direct subsidies promote the technology, encourage market growth and result in rapid technology learning, achieving lower unit production costs more quickly than alternative policies. However, many economists argue that FITs and other subsidies are inefficient in promoting the uptake of low carbon technologies since politicians are not normally successful in picking winners and losers (Lesser and Su, 2008); rather, it is argued that carbon taxes are preferable since the market will respond by adopting the most economically efficient measures available. Indeed, numerous carbon dioxide marginal abatement cost studies indicate that PV is currently a relatively expensive technology compared to alternative abatement technologies, such as house insulation (Enkvist et al., 2007; Kesicki and Strachan, 2011).

Advanced FITs are higher tariffs for the electricity generated which recognise its time-of-use value (e.g. production at peak demand times associated with air conditioning loads), its distributed benefits (e.g. avoiding investment in network capacity) and the avoided environmental costs (e.g. associated with poor air quality and greenhouse gas emissions) (Paul, 2008).

\subsection{PV FITs in different countries}

A number of FIT schemes have been introduced in Europe and Australia since 2008. This has resulted in strong growth in PV markets in France, Germany, 
Italy, Korea, Portugal and Spain (Photovoltaic Power Systems Programme, 2008). Germany's programme has been particularly successful when measured by new PV installed capacity, although the technology accounted for only $1.1 \%$ of the nation's total electricity generation capacity in 2009 (European Commission, 2012). Table 1 shows details of purchase conditions for PV electricity in some countries.

The UK FIT scheme was introduced in April 2010 to promote the uptake of small-scale electricity generation from a range of technologies which include: hydro; photovoltaic; wind; and micro combined heat and power ( $\mu$-CHP). The PV FIT provided a generation tariff paid per $\mathrm{kWh}$ for different types of installations and included a low export tariff (amount paid when energy is fed into the grid) of 0.030 $\mathrm{f} / \mathrm{kWh}$ when compared to that for electricity generated and consumed on-site ( $£ 0.330$ to $£ 0.413$ - see Table 2 ), thus incentivising on-site consumption. Payments are guaranteed for 25 years and are linked to inflation. It is estimated that this tariff level will result in 7-8\% annual returns for homeowners who retrofit PV systems less than $4 \mathrm{~kW}_{\mathrm{p}}$ (Department of Energy and Climate Change, 2010).

The low export tariff for power delivered by households to the grid helps to compensate the utility for providing back-up capacity and to maintain the distribution infrastructure, while avoiding some distribution losses and upgrade costs. This would not be the case if the FIT rate was the same as the customer's rate for power delivered by the utility to the customer. Table 2 shows details of the FIT structure in the UK.

Three types of microgeneration FITs are distinguished in literature, each relating to one of the metering arrangments described previously: 
- where the FIT applies to all PV generated electricity (gross metering), which is used in Germany, Spain, Italy, Greece and Portugal;

- where it applies to the net quantity of electricity exported (net metering) such as in some states in the USA and Australia; and

- where different tariffs apply to the quantity of generated electricity and used on-site with a separate tariff for the portion exported to the grid (smart metering) as is now applicable in the UK.

\section{Table 1}

Current purchase conditions for PV electricity in some EU countries Source: (Eurobserv'er, 2009)

\begin{tabular}{|c|c|c|c|c|c|c|c|}
\hline \multirow[b]{2}{*}{ Country } & \multirow[b]{2}{*}{$\begin{array}{l}\text { Guarantee } \\
\text { Period } \\
\text { (years) }\end{array}$} & \multirow[b]{2}{*}{$\begin{array}{l}\text { Year of } \\
\text { Implementation }\end{array}$} & \multirow{2}{*}{$\begin{array}{l}\text { PV } \\
\text { System } \\
\text { Capacity } \\
\text { (kWp) }\end{array}$} & \multirow[b]{2}{*}{ Details } & \multicolumn{3}{|c|}{ Feed-in tariff $(\mathrm{c} / \mathrm{kWh})$} \\
\hline & & & & & Rooftop & $\begin{array}{l}\text { Ground- } \\
\text { based }\end{array}$ & $\begin{array}{l}\text { Building } \\
\text { Integrated }\end{array}$ \\
\hline Germany & 20 & 2011 & $\leq 30$ & & 36 & 26.2 & - \\
\hline & & & $1-3$ & & 44 & 40 & 49 \\
\hline Italy & 20 & 2008 & $>3-20$ & & 42 & 38 & 46 \\
\hline Spain & 25 & 2009 & $\leq 10$ & & 34 & 32 & - \\
\hline $\begin{array}{l}\text { Czech } \\
\text { Republic }\end{array}$ & 20 & 2008 & All sizes & $\begin{array}{l}\text { Standard } \\
\text { Green } \\
\text { premium }\end{array}$ & $\begin{array}{l}51.2 \\
48.1 \\
\end{array}$ & & \\
\hline Greece & 10 & 2008 & $<100$ & $\begin{array}{l}\text { Mainland } \\
\text { Islands }\end{array}$ & $\begin{array}{l}45.3 \\
50.3 \\
\end{array}$ & & \\
\hline Portugal & 15 & 2008 & $\leq 3.7$ & & 65 & & \\
\hline Australia & - & - & $\leq 10$ & & $20-68^{2}$ & & \\
\hline
\end{tabular}

Table 2

UK Feed-in tariff structure for PV-generated electricity used on-site Source: (Department of Energy and Climate Change, 2010)

\begin{tabular}{lcccc}
\hline Installation size & \multicolumn{3}{c}{ Price paid for energy generated $(\mathrm{p} / \mathrm{kWh})$} & \multirow{2}{*}{ Lifetime } \\
\cline { 2 - 4 } & Year 1 & Year 2 & Year 3 & \\
\hline $4 \mathrm{~kW}_{\mathrm{p}}$ (new build) & 36.1 & 36.1 & 33.0 & 25 \\
$4 \mathrm{~kW}_{\mathrm{p}}$ (retrofit) & 41.3 & 41.3 & 37.8 & 25 \\
$4-10 \mathrm{~kW}_{\mathrm{p}}$ & 36.1 & 36.1 & 33.0 & 25 \\
\hline
\end{tabular}

\footnotetext{
${ }^{2}$ The FIT is based on either the total quantity of electricity generated as well as the net quantity exported to the grid.
} 
Table 3 shows a comparative assessment of the characteristics, advantages and disadvantages of different microgeneration FIT policies worldwide.

\section{Table 3}

Comparative assessment of FIT policies

\begin{tabular}{|c|c|c|c|}
\hline Policy & Characteristics & Advantages & Disadvantages \\
\hline Net metering & $\begin{array}{l}\text { Electricity } \\
\text { imported } \\
\text { exported and } \\
\text { same cost. }\end{array}$ & $\begin{array}{l}\text { Easy to implement. } \\
\text { Requires simple } \\
\text { metering which is } \\
\text { often in place. }\end{array}$ & $\begin{array}{l}\text { Does not guarantee } \\
\text { economic viability to } \\
\text { investor since net } \\
\text { amount may vary. } \\
\text { No opportunity to } \\
\text { target rewards at } \\
\text { renewable energy } \\
\text { produced. }\end{array}$ \\
\hline Gross metering & $\begin{array}{l}\text { High FIT offered for } \\
\text { all } \quad \text { electricity } \\
\text { generated. }\end{array}$ & $\begin{array}{l}\text { Easy to design and } \\
\text { implement. Ensures } \\
\text { a predefined rate of } \\
\text { return on } \\
\text { investment for a } \\
\text { targeted PV system } \\
\text { size. }\end{array}$ & $\begin{array}{l}\text { No incentive for on- } \\
\text { site electricity use. }\end{array}$ \\
\hline Smart metering & $\begin{array}{l}\text { High FIT for total } \\
\text { electricity generated } \\
\text { and low FIT for } \\
\text { spilled electricity. }\end{array}$ & $\begin{array}{l}\text { Ensures } \\
\text { predefined rate of } \\
\text { return on } \\
\text { investment for a } \\
\text { targeted PV system } \\
\text { size. Real time and } \\
\text { historic metering } \\
\text { data can be used for } \\
\text { many other } \\
\text { purposes. }\end{array}$ & $\begin{array}{l}\text { May encourage } \\
\text { electricity wastage. } \\
\text { Can result in both } \\
\text { low and windfall } \\
\text { returns if not } \\
\text { efficiently designed. } \\
\text { Expensive smart } \\
\text { meter required. }\end{array}$ \\
\hline
\end{tabular}

\section{FIT Design Methodology}

The FIT design methodology described and implemented in this paper is based on a smart metering arrangement, where different tariffs apply to PV electricity consumed on the premises and that spilled onto the grid. This reflects the fact that on-site consumption is more advantageous due to avoided distributional losses and grid upgrade costs. The FIT applies to the total quantity of electricity generated; spill electricity attracts the same tariff as the wholesale price 
of electricity. The value to the homeowner of the electricity produced, however, is greater for on-site consumption where it is the sum of the FIT earned and the domestic buy-in tariff avoided as shown in Fig. 2.

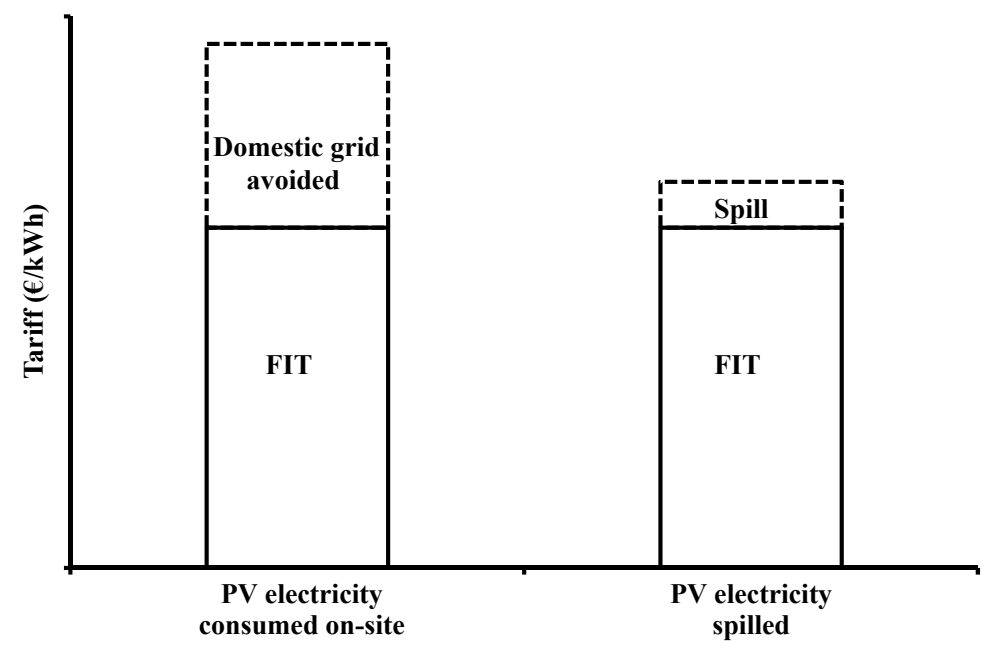

Fig. 2. Value of PV generated electricity to the homeowner for both on-site and spill electricity

The methodology first involves choosing the most appropriate domestic PV system. The system's electricity outputs are estimated for the relevant region in time-steps which correspond to the smart meter sampling time interval. These outputs are then combined with a representative sample of household smart metering data to quantify the amount of spill and on-site consumption for each time interval and household. Financial techniques are used to calculate the FIT required for each household to incentivise investment and the distribution of required FITs is plotted. The economic efficiency of a number of FIT policies (e.g. single and multiple FITs) can then be estimated for the population using this distribution. A flow chart of the methodology is shown in Fig. 3. 


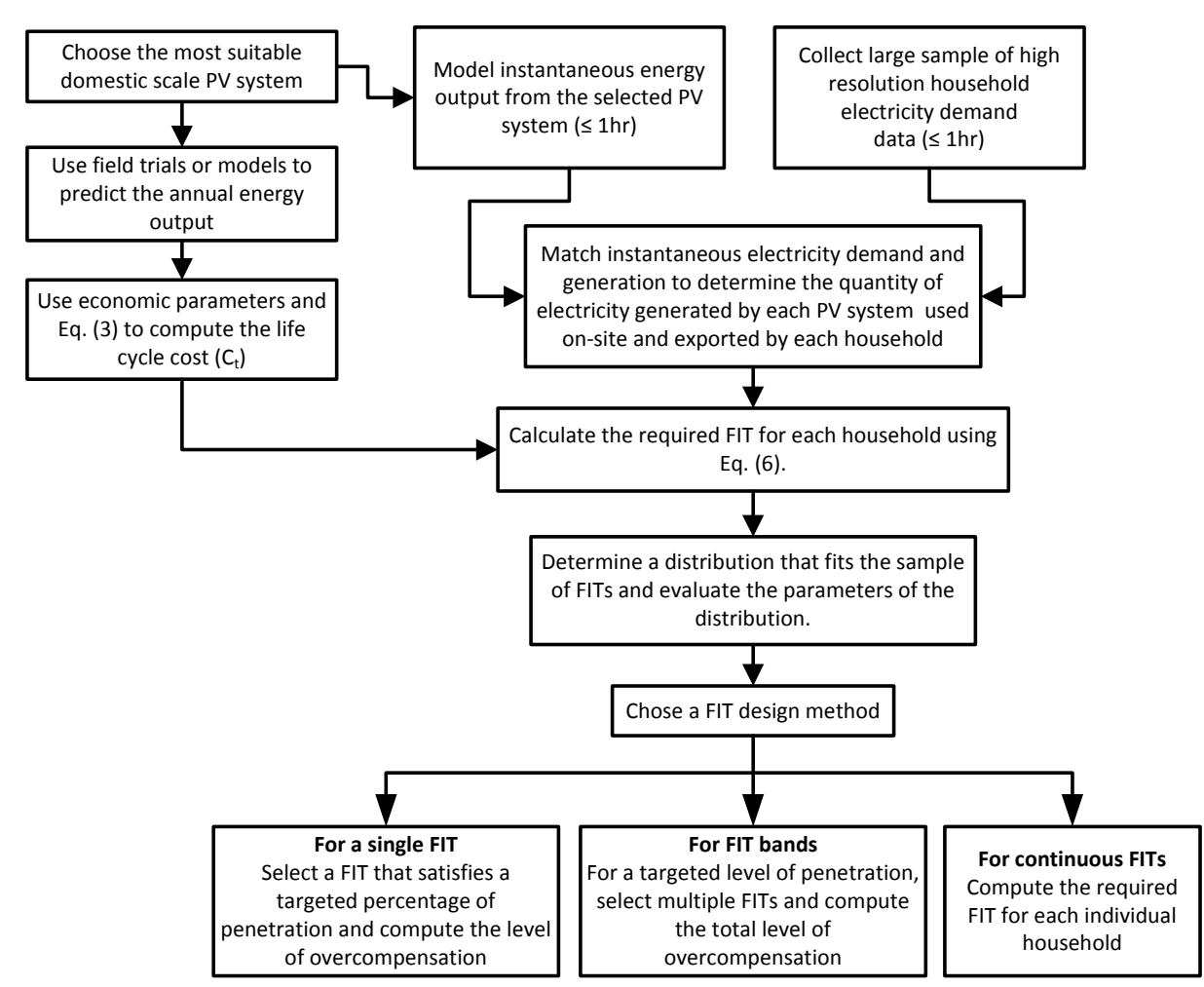

Fig. 3. Flow chart of the proposed FIT design methodology

\subsection{PV electricity generation}

Field performance monitoring data from Ayompe et al. (2011) showed that the annual yield of a south-facing, free-standing mono-crystalline PV system in Dublin, Ireland was $885.1 \mathrm{kWh} / \mathrm{kW}_{\mathrm{p}}$. However, widely-deployed roof-mounted domestic systems would not all be south-facing or as well-ventilated and so would have a lower yield. Therefore, the available solar resource was decreased. For typical roof pitches of $40-45^{\circ}$ in Ireland, peak isolation levels (at an azimuth of $0^{\circ}$ ) decrease by approximately $17 \%$ for a $90^{\circ}$ azimuth (Mondol et al. 2007). A review of building orientations using Google Earth indicated them to be randomly distributed nationally; insolation levels were decreased by an average of $8.5 \%$ accordingly. 
Insolation levels were also decreased by $3.5 \%$ to account for higher PV module temperature (Earthscan, 2008). Consequently, the annual yield was derated by a total of $12 \%$ to $778.9 \mathrm{kWh} / \mathrm{kW}_{\mathrm{p}}$ compared to that reported in Ayompe et al. (2011).

An analaysis of Irish PV systems by the authors showed that $1.72 \mathrm{~kW}_{\mathrm{p}}$ and $2.82 \mathrm{~kW}_{\mathrm{p}}$ installations have the lowest levelised cost of electicity production. The larger $2.82 \mathrm{~kW}_{\mathrm{p}}$ PV system was chosen for the analysis in this paper. This is similar to the $2.9 \mathrm{~kW}_{\mathrm{p}}$ average capacity of domestic grid-connected PV systems installed in the UK in 2010/11 (OFGEM, 2012).

\subsection{Domestic electricity demand profiles}

The electricity demand profiles used in this study are from a sample of 3,889 households obtained from an electrical smart metering survey performed by the largest Irish domestic energy supplier, Electric Ireland. Electricity demand was measured at 30-minute intervals for each domestic dwelling for a year. It was assumed that the annual electricity demand profiles remain constant throughout the useful life of the PV system since there is no data available on how these profiles change over long time-periods.

\subsection{Interaction of PV Electricity Generation and Domestic Electricity Profiles}

Electricity output from PV systems does not match typical domestic household demand patterns. This is illustrated in Fig. 4 which shows electricity demand for a dwelling during a weekday in summer together with the output for a range of PV system sizes for a typical summer day in Ireland. The observed mismatch between PV supply and domestic demand leads to a portion of the 
generated electricity to be exported, or "spilled" to the grid. The quantity of exported electricity depends on a variety of factors, the most important of which are: the PV system size; solar energy resource; time of year; and the household electricity demand profile. A variety of factors must be taken into consideration to size the PV system efficiently including: quantities of production; import and export tariffs; capital costs; and cost of capital. Time of day tariffs would add complexity and, although not considered further here, can be accommodated by the proposed FIT design method.

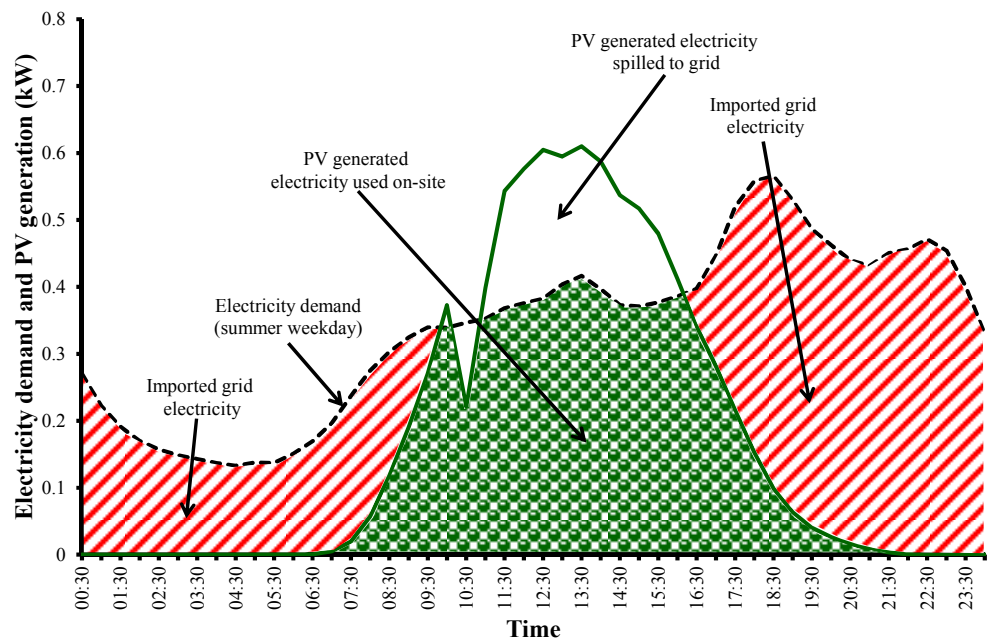

Fig. 4. Sample daily household electricity demand (Electric Ireland and SEAI, 2012) and electricity generation by a PV system.

The percentage of on-site household electricity use is given as:

$$
E_{o n}=\frac{100}{N} \sum_{t=1}^{N}\left(\frac{E_{o n, t}}{P V_{t}}\right)
$$

For a given time, $t$, if $E_{d, t}<P V_{t}$, then $E_{o n, t}=E_{d, t}$ while if $E_{d, t} \geq P V_{t}$, then $E_{o n, t}=P V_{t}$. Eq.

(1) is valid only when $P V_{t}>0$.

$E_{\text {on }} \quad$ percentage on-site household electricity use (\%) 
$\mathrm{N}$ number of 30 -minute time intervals i.e. 17,520

$E_{d, t} \quad$ electricity demand at time, $t(k W h)$

$E_{o n, t} \quad$ electricity used on-site at time, $t(k W h)$

$\mathrm{PV}_{\mathrm{t}} \quad \mathrm{PV}$ generated electricity at time, $\mathrm{t}(\mathrm{kWh})$

\subsection{PV system costs}

The installed cost of a roof mounted, grid-connected PV system depends on its capacity, type of PV modules, roof type and orientation on which it is to be installed, cost of balance of system (BOS) components and local market conditions. BOS cost accounts for all other PV system components except the modules and includes costs associated with mounting structures, installation, commissioning, design, metering, inverter, cabling and wiring. The present value of the total life cycle cost of the PV system is the sum of the present value of costs associated with the PV module, initial BOS, replacement cost of BOS and operation and maintenance (O\&M) cost. The present value of total life cycle cost of the PV system $\left(C_{t}\right)$ is given as (Bhandari and Stadler, 2009):

$\mathrm{C}_{\mathrm{t}}=\mathrm{C}_{\mathrm{mt}}+\mathrm{C}_{\mathrm{BOS}}+\mathrm{C}_{\text {BOSrep }}+\mathrm{C}_{\mathrm{v}}$

and is written as:

$\mathrm{C}_{\mathrm{t}}=\mathrm{C}_{\mathrm{m}} \mathrm{P}_{\text {peak }}\left[1+\mathrm{k}_{\text {BOS }}+\mathrm{k}\left\{\sum_{\mathrm{n}=1}^{\mathrm{n}=\mathrm{N}_{\mathrm{r}}} \frac{\mathrm{k}_{\text {BOS }} \mathrm{k}_{\text {BOSrep }}}{(1+\mathrm{d})^{\left(\mathrm{N}_{\mathrm{r}}\right)}}\right\}+\mathrm{k}_{\mathrm{v}}\left\{\sum_{\mathrm{n}=1}^{\mathrm{n}=\mathrm{N}} \frac{(1+\mathrm{d})^{\mathrm{n}}-1}{\mathrm{~d}(1+\mathrm{d})^{\mathrm{n}}}\right\}\right]$

The PV module price reduction factor $(k)$ is given as:

$\mathrm{k}=\frac{\mathrm{C}_{\mathrm{m}\left(\mathrm{n}+\mathrm{N}_{\mathrm{r}}\right)}}{\mathrm{C}_{\mathrm{m}(\mathrm{n})}}$ 
where,

$C_{t} \quad$ present value of total life cycle cost of the PV system $\left(€_{2013}\right)$

$\mathrm{C}_{\mathrm{mt}} \quad$ present value of cost associated with PV module $\left(€_{2013}\right)$

$C_{\text {BOS }}$ present value of cost associated with the initial investment on BOS $\left(€_{2013}\right)$

$C_{\text {BOSrep }}$ present value of BOS replacement cost $\left(€_{2013}\right)$

$\mathrm{C}_{\mathrm{v}} \quad$ present value of total O\&M cost $\left(€_{2013}\right)$

d discount rate $(\%)$

$\mathrm{k}_{\mathrm{BOS}} \quad$ BOS cost factor (dimensionless)

$\mathrm{k}_{\text {BOSrep }}$ balance of system replacement cost factor (dimensionless)

N PV system life (years)

$\mathrm{N}_{\mathrm{r}} \quad$ BOS component life time (years)

$P_{\text {peak }} \quad \mathrm{PV}$ system peak power $\left(\mathrm{kW}_{\mathrm{p}}\right)$

$C_{m} \quad$ normalise PV module cost $\left(€ / \mathrm{kW}_{\mathrm{p}}\right)$

\subsection{Revenue}

Revenue depends primarily on the amount of electricity produced by the PV system (system yield) and is a function of the electricity load profile of the PV owner, import and export tariffs, as well as policy incentives (FITs). The present value of total revenue can be calculated as (Candelise et al., 2010):

$$
\mathrm{R}_{\mathrm{t}}=\sum_{\mathrm{n}=1}^{\mathrm{n}=\mathrm{N}}\left(\alpha_{\mathrm{n}} \mathrm{AI}+\beta \mathrm{TG}+\gamma_{\mathrm{n}} \mathrm{EX}\right)(1+\mathrm{d})^{-\mathrm{n}}
$$

$R_{t} \quad$ present value of total revenue $(€)$

Al avoided electricity import (kWh)

EX electricity exported (kWh) 
$\alpha_{n} \quad$ electricity import tariff in year " $n$ " (€/kWh)

$\beta \quad$ generation based reward or FIT $(€ / \mathrm{kWh})$

$V_{n} \quad$ electricity export tariff in year " $n$ " $(€ / k W h)$

N PV system useful life (years)

d discount rate (\%)

\subsection{Required FIT}

The FIT required to make the investment financially attractive to an economically rational investor was calculated by setting the net present value (NPV) of the PV system to zero and solving for FIT for each household. The NPV method involves first estimating the present values of all the cash inflows and outflows of an investment at a given target rate of return or cost of capital, and then determining net total discounted revenues. This is the difference between the present values of costs $\left(C_{t}\right)$ and revenues $\left(R_{t}\right)$. In mathematical terms, NPV is expressed as (Power et al., 2009):

$N P V=R_{t}-C_{t}$

Projects with a positive NPV are deemed acceptable or viable while those that exhibit a negative NPV are considered to be unacceptable (Brockington, 1993).

Real discount rates ranging between $3 \%$ and $22.5 \%$ have been used by various researchers to evaluate the economic viability of PV systems (McHenry, 2012; Nfah, 2013; and Poponi, 2003) and investment in household durables (Heuston, 1983). In this study, four discount rates notably $5 \%, 10 \%, 15 \%$ and $20 \%$ were used. Cashflows are estimated over 25 years which reflects both the useful 
PV system life and typical FIT gurantee periods (see Table 1). A $0.82 \%$ annual degradation factor is assumed for PV panels electricity generation over the PV system's life cycle (Osterwald et al., 2002). Domestic electricity (including taxes) and electricity export (wholesale) tariffs are $0.2 € / \mathrm{kWh}$ and $0.05 € / \mathrm{kWh}$ respectively.

The FIT required to ensure economic viability is obtained by setting the NPV in Equation 5 equal to zero and substituting the expressions for the present values of total life cycle cost $\left(C_{t}\right)$ in Eq. (3) and total revenue $\left(R_{t}\right)$ in Eq. (4). This results in an expression for the required FIT given as:

$$
\beta=\frac{1}{\operatorname{TG} \sum_{\mathrm{n}=1}^{\mathrm{N}}(1+\mathrm{d})^{-\mathrm{n}}}\left(\mathrm{C}_{\mathrm{t}}-\alpha \sum_{\mathrm{n}=1}^{\mathrm{N}} \operatorname{AI}(1+\mathrm{d})^{-\mathrm{n}}-\gamma \sum \operatorname{EX}(1+\mathrm{d})^{-\mathrm{n}}\right)
$$

In this way the required FIT for each household is calculated. Values are then put into suitable bins, a histogram plotted on which a probability density function of the FITs is fitted.

\subsection{Economic efficiency}

When an FIT is chosen by a government or utility, all homeowners for whom the FIT level will result in an NPV $\geq 0$ will be incentivised to invest. An infinitesimal number will achieve an NPV=0 (or very close to this). However, the remainder will be overcompensated. This overcompensation can be estimated using the distribution of required FITs calculated above (Eq. (7)). The manner in which overcompensation was calculated for single and multiple FITs is described below. 


\subsubsection{Single FIT}

For a given PV system size, an FIT that ensures economic viability (NPV $\geq 0$ ) for a targeted level of penetration is chosen. The methodology assumes that households with NPV $<0$ would not adopt a PV system under the FIT while those with NPV $\geq 0$ would install PV systems under the FIT. For example, an FIT of 0.3475 $€ / \mathrm{kWh}$ and a real discount rate of $15 \%$ results in a probability density function of 0.75 (see Fig. 5). This implies that this FIT would result in an NPV $\geq 0$ for $75.0 \%$ of the sample population. The single FIT is however, not economically efficient since it results in households being overcompensated.

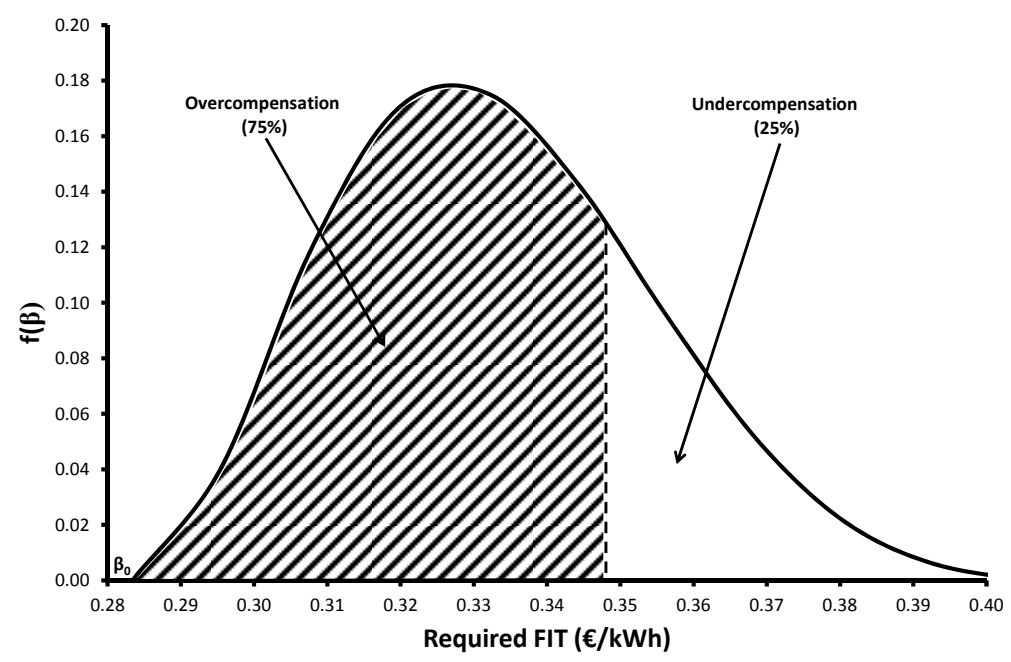

Fig. 5. Overcompensation and undercompensation for a single FIT

The total overcompensation amount for a single FIT is given as:

$$
\mathrm{OC}=\left[\mathrm{N}_{\mathrm{s}} \mathrm{G}_{\mathrm{n}} \int_{\beta_{0}}^{\beta_{1}}\left(\beta_{1}-\beta\right) f(\beta) \mathrm{d} \beta\right] \sum_{\mathrm{n}=1}^{\mathrm{N}}(1+\mathrm{d})^{-\mathrm{n}}
$$

where,

OC is the total level of overcompensation in the sample (€) 
$\beta \quad$ is the required FIT for a given household $(€ / \mathrm{kWh})$

$\beta_{1} \quad$ is the chosen FIT (0.3475 $€ /$ kWh in Fig. 5)

$\beta_{0} \quad$ is the lower FIT bound (0.2834 €/kWh in Fig. 5)

$N_{s} \quad$ is the sample size $(2,551$ for this study)

$\mathrm{G}_{\mathrm{n}} \quad$ net electricity generation in year $\mathrm{n}(\mathrm{kWh})$

d discount rate $(\%)$

$\mathrm{N} \quad$ number of years of investment (25 yrs)

\subsubsection{Multiple FITs}

Multiple FIT bands can be designed to target groups of households with similar required FITs. This entails grouping the required FITs into bands and identifying important characteristics common to households in these bands. This results in a reduction in the level of overcompensation thereby improving the economic efficiency of the FITs. Fig. 6 shows three FIT bands with $0-25 \%, 25-50 \%$ and $50-75 \%$ of overcompensation and one band with undercompensation. The level of overcompenstion is calculated using Eq. (8).

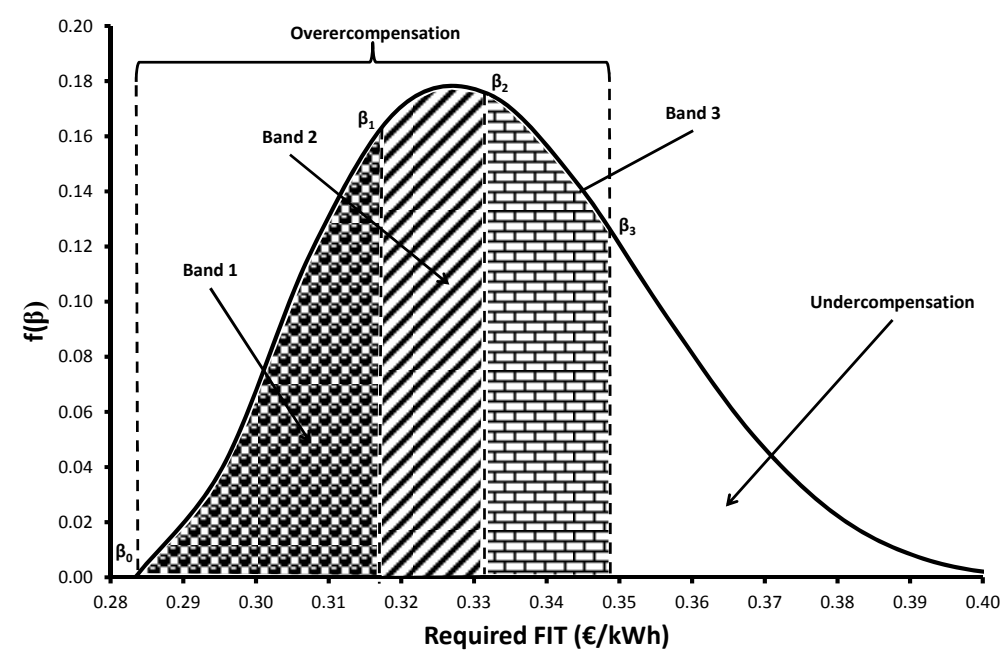

Fig. 6. Multiple FIT bands 
The total overcompensation amount for multiple FIT bands is given as:

$$
\mathrm{OC}=\left\{\mathrm{N}_{\mathrm{s}} \mathrm{G}_{\mathrm{n}}\left[\int_{\beta_{0}}^{\beta_{1}}\left(\beta_{1}-\beta\right) f(\beta) \mathrm{d} \beta+\int_{\beta_{1}}^{\beta_{2}}\left(\beta_{2}-\beta\right) f(\beta) \mathrm{d} \beta+\int_{\beta_{2}}^{\beta_{3}}\left(\beta_{3}-\beta\right) f(\beta) \mathrm{d} \beta\right]\right\} \sum_{\mathrm{n}=1}^{\mathrm{N}}(1+\mathrm{d})^{-\mathrm{n}}
$$

where, $\beta_{1}, \beta_{2}$ and $\beta_{3}$ are the chosen FITs ( $€ / \mathrm{kWh}$ ) for bands 1,2 and 3 respectively. $\beta$ is the required FIT (€/kWh).

\subsubsection{Continuous FITs}

With smart metering data, it is also possible for FITs to be efficiently designed for individual households. This entails designing the required FITs for each household separately. For a given PV system size, a continuous stream of FITs would be obtained which would lie along the plot of the probability density function shown in Fig. 7. For a given household, the required FIT would result in a NPV of 0 . This results in an ideal, efficient FIT design with no overcompensation or undercompensation. 


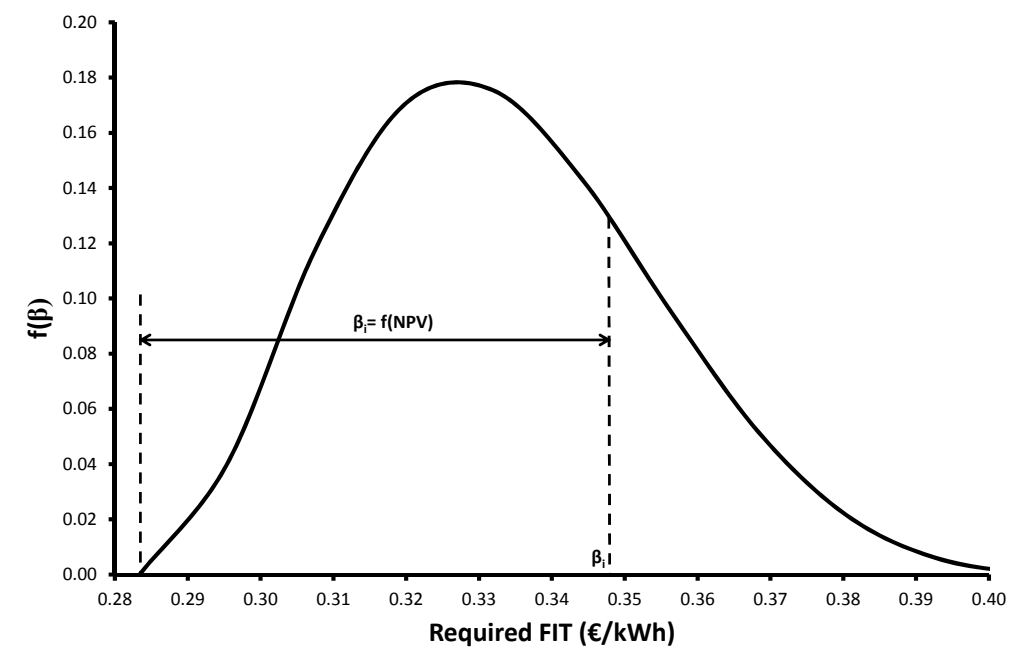

Fig. 7. Continuous FITs

\section{Results and Discussions}

\subsection{Domestic electricity demand profiles}

Total annual electricity consumption of the sample of smart metered houses ranged from $1,035.5 \mathrm{kWh}$ to $14,959.9 \mathrm{kWh}$ with mean of 7,863.9 $\mathrm{kWh}$ and standard deviation of 3,322.9 $\mathrm{kWh}$. The average daily electricity consumption was $21.5 \mathrm{kWh}$. Fig. 8 shows the frequency distribution of the average annual electricity consumption for the sampled households. It is seen that the band between 1,000 and $2,000 \mathrm{kWh}$ has the lowest frequency distribution of $2.0 \%$ while the band between 7,000 and $8,000 \mathrm{kWh}$ has the highest frequency distribution of $10.6 \%$. Over $85 \%$ of the sampled households have average annual electricity demands between 3,000 and 13,000 kWh. The data showed that average electricity demand varied between weekdays and weekends as well as between seasons as shown in Figs. 9 and 10. 


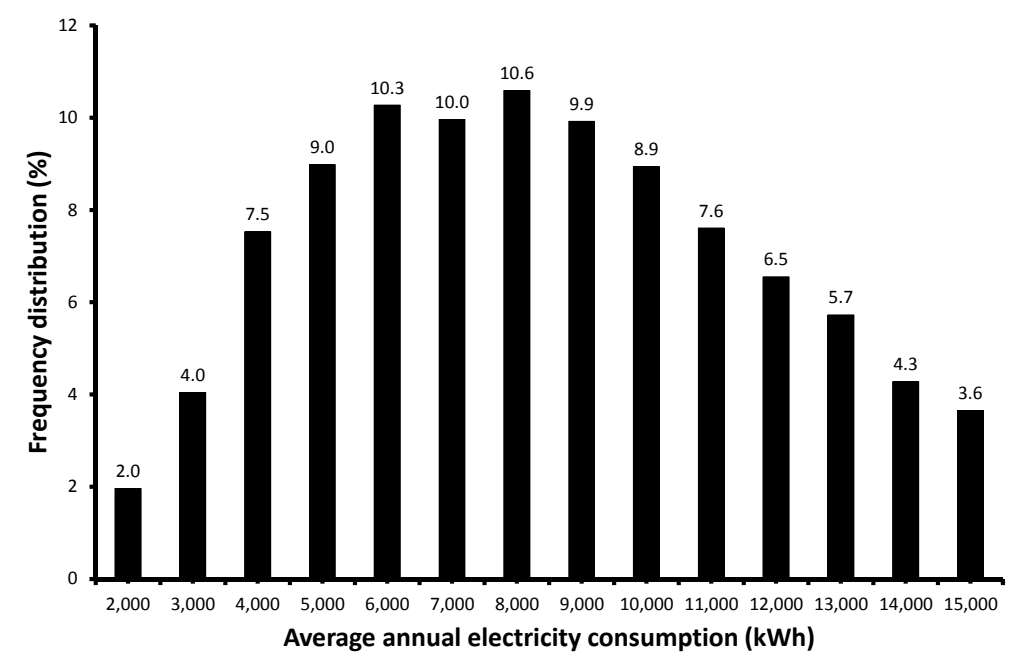

Fig. 8. Frequency distribution of average annual electricity consumption for the sampled households (Electric Ireland and SEAI, 2012)

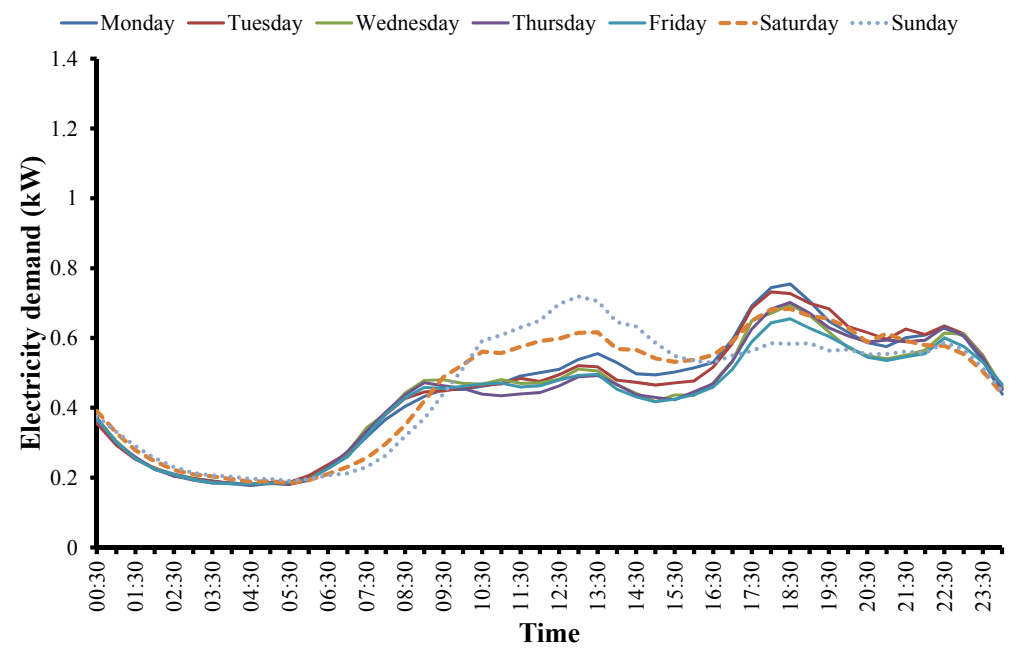

Fig. 9. Average weekly summer electricity demand profiles for residential households (Electric Ireland, 2010) 


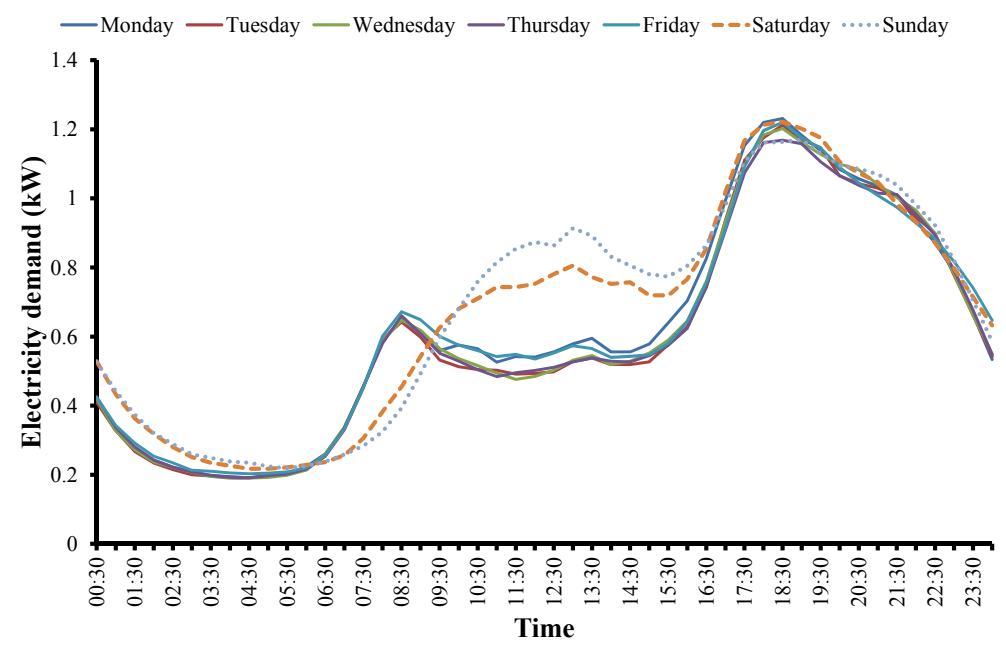

Fig. 10. Average weekly winter electricity demand profiles for residential households (Electric Ireland and SEAI, 2012)

\subsection{PV system costs}

Table 4 shows a detailed breakdown of the installed cost for the $2.82 \mathrm{~kW}_{\mathrm{p}}$ PV system obtained in April 2013 from installers in Ireland. The total PV system cost is broken down into its component parts notably: PV modules and BOS. The normalised installed system cost was $2,600 € / \mathrm{kW}_{\mathrm{p}}$ while the proportion of BOS cost relative to total cost was $56.3 \%$. The PV module and system costs were $€ 3,200$, and $€ 7,331$ respectively. Annual operation and maintenance costs mainly account for the inverter replacement and has widely been quoted to be 1 per cent of the initial system capital cost (Watson et al., 2006; Bhandari and Stadler, 2009). 


\section{Table 4}

Detailed breakdown of installed cost of the PV system in Ireland (2013)

\begin{tabular}{ll}
\cline { 2 - 2 } Item description & Value \\
\cline { 2 - 3 } PV module cost $(€)$ & 3,200 \\
Inverter cost $(€)$ & 1,725 \\
Cost of other components \& installation & \\
$(€)$ & 2,406 \\
\hline Total cost $(€)$ & 7,331 \\
\cline { 2 - 2 } Normalised PV module cost $\left(€ / \mathrm{kW}_{\mathrm{p}}\right)$ & 1,135 \\
\hline Normalised system cost $\left(€ / \mathrm{kW}_{\mathrm{p}}\right)$ & 2,600 \\
\hline BOS percentage $(\%)$ & 56.3 \\
\hline O\&M cost $(€ / \text { annum })^{*}$ & 73.3 \\
\hline
\end{tabular}

${ }^{*}$ Represents $1 \%$ of initial capital cost

The present value of the total life cycle cost of the $2.82 \mathrm{kWp}$ PV system was found to be $€ 8,105$.

\subsection{Required FIT}

The level of support or FIT required to make it worthwhile to invest (NPV=0) in the $2.82 \mathrm{~kW}_{\mathrm{p}}$ was calculated for each of the 2,551 households using Eq. (6). A frequency distribution chart of the required FITs for each household was plotted in order to obtain a probability density function of the FITs with a suitable fit. Fig. 11 shows beta distribution probability density function plots of the required FITs for different discount rates which make it worthwhile for all households to invest in the $2.82 \mathrm{~kW}_{\mathrm{p}}$ PV system. The probability density function gives the values that the FITs may assume and their probabilities. Therefore, for a given FIT, we can obtain the fraction of households that would be targeted. The beta distribution probability density function in Eq. 9 with parameters $(p, q, a, b$ for different discount rates shown in Table 5) was seen to provide a good fit. 
The general formula for the probability density function of the beta distribution is given as (Marques de Sá, 2007)

$f(\beta)=\frac{(\beta-a)^{p-1}(b-\beta)^{q-1}}{B(p, q)(b-a)^{p+q-1}}, a \leq \beta \leq b ; p, q>0$

where the beta function $B(p, q)$ is given as

$B(p, q)=\frac{\Gamma(p) \Gamma(q)}{\Gamma(p+q)}, p, q>0$

and $p$ and $q$ are the shape parameters while $a$ and $b$ are the lower and upper bounds, respectively, of the distribution.

Table 5

Beta distribution parameters for different discount rates

\begin{tabular}{ccccc}
\hline $\begin{array}{c}\text { Discount } \\
\text { rate (\%) }\end{array}$ & $\mathrm{p}$ & $\mathrm{q}$ & $\mathrm{a}$ & $\mathrm{B}$ \\
\hline 5 & 3.276 & 6.3458 & 0.0633 & 0.2322 \\
10 & 3.269 & 6.3055 & 0.1589 & 0.3273 \\
15 & 3.273 & 6.3057 & 0.2589 & 0.4273 \\
20 & 3.317 & 6.4712 & 0.3572 & 0.5277 \\
\hline
\end{tabular}




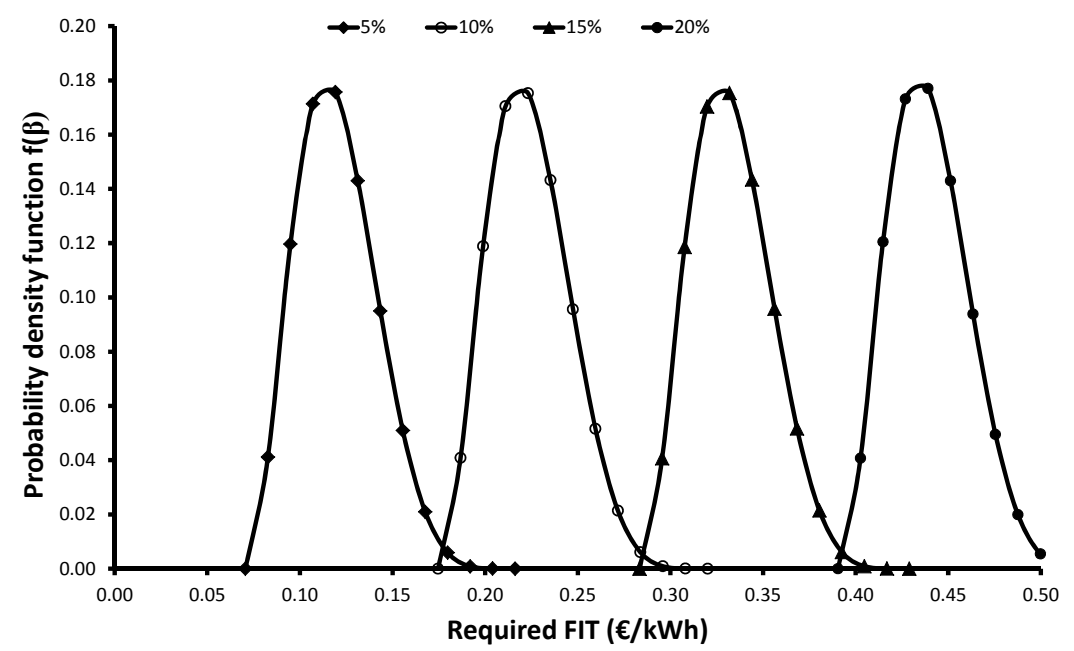

Fig. 11: Beta distribution probability density function against required FITs for different discount rates

There is a high negative correlation $\left(R^{2}=0.782\right)$ between the required FIT for each household and its annual electricity consumption as shown in Fig. 12 (for a $15 \%$ discount rate). One option would be to use this relationship to target households with specific FIT bands.

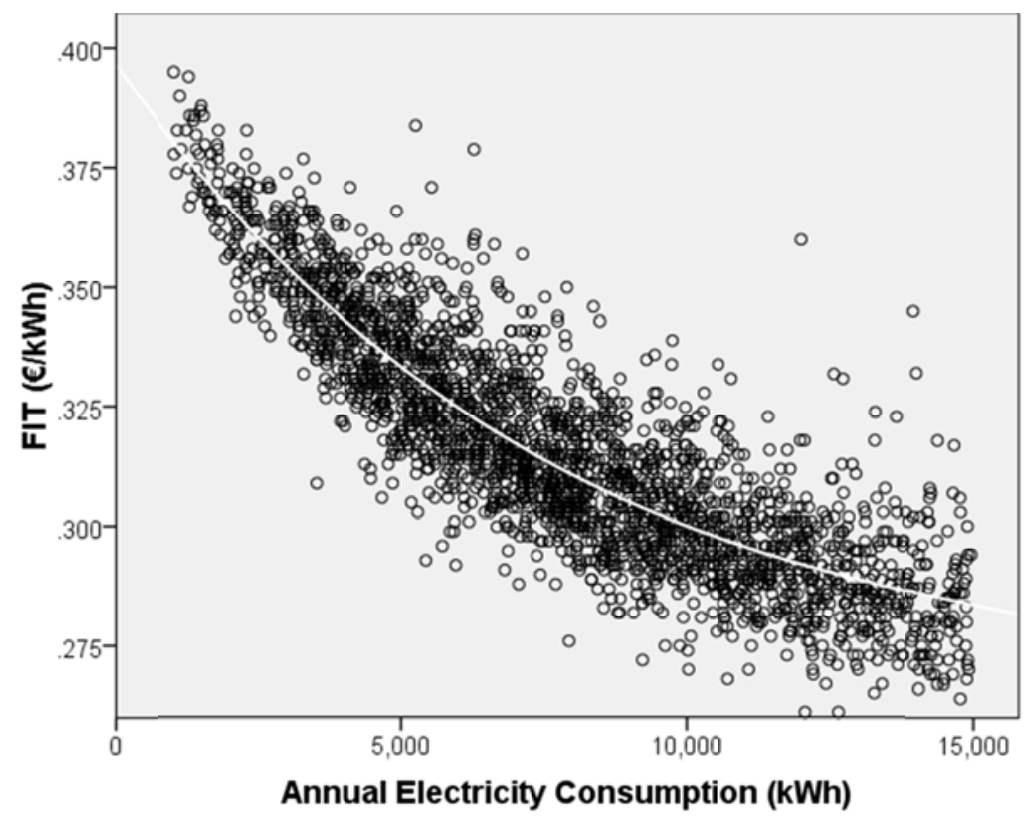

Fig. 12: Scatter plot showing correlation between household annual electricity consumption and required FIT for a $15 \%$ discount rate. 


\subsection{Economic efficiency}

$82.6 \%$ of dwellings in Ireland are houses; assuming that $25 \%$ of these are unsuitable for PV installations due to overshading and structural limitations, then there is a market of $1,059,328$ permanently occupied dwellings. Taking this population of households to be economically rational and having perfect information, then they will adopt the technology when the required FIT is set so that their NPV $\geq 0$.

The level of overcompensation was calculated for single and multiple FITs designed to incentivise $75 \%$ of this market using Eqs 9 and 10 respectively. Table 5 shows the level of overcompensation that would arise if all eligible households were to install a $2.82 \mathrm{~kW}_{\mathrm{p}}$ PV system at a discount rate of $15 \%$. A single FIT of $0.3475 € / \mathrm{kWh}$ would result in a total lifecycle overcompensation of $€ 597,163,518$ to 794,496 households. However, if a multiple FIT approach were adopted where three tariffs of $0.3170,0.3315$ and $0.3475 € / \mathrm{kWh}$ were offered to incentivise $25 \%$, $50 \%$ and $75 \%$ of the market respectively, then the total overcompensation would decrease to $€ 240,986,085$ which is $59.6 \%$ lower than the total overcompensation for the single FIT. The total lifecycle cost to the taxpayer or electricity consumer (depending how it is funded) of such a programme is the discounted product of the FIT and all units of electricity produced over 25 years. Again assuming a $75 \%$ uptake, the total programme cost is $€ 3.964 \mathrm{bn}$. Single and mulitple tariff overcompensations represent $15.1 \%$ and $6.1 \%$ of this cost respectively. These percentages will increase for lower lifecycle costs and FITs resulting from, for example, reduced system costs or discount rates. 
The results show that although both FIT design methods are economically inefficient, splitting the FIT into bands that target households with the same characteristics would be more efficient.

Table 6

Population targeted and overcompensation for single FIT and multiple FITs using a $15 \%$ discount rate.

\begin{tabular}{cccc}
\hline & & \multicolumn{2}{c}{ Overcompensation $(€)$} \\
\cline { 3 - 4 } FIT $(€ / \mathrm{kWh})$ & Number of & Single & Multiple \\
& households & FIT & FITs \\
\hline 0.3170 & 264,832 & & $126,320,319$ \\
0.3315 & 529,664 & & $54,513,233$ \\
0.3475 & 794,496 & $597,163,518$ & $60,152,533$ \\
\hline Total & & $597,163,518$ & $240,986,085$ \\
\hline
\end{tabular}

\section{Conclusion}

The advent of large samples of smart metering data allows policymakers to design FITs which are more targeted and efficient. This paper presents a methodology which uses these data to design FITs for domestic scale gridconnected PV systems in Ireland. A sample of 2,551 household electricity demand data collected at $1 / 2$-hourly intervals, electricity output from a $2.82 \mathrm{~kW}_{\mathrm{p}} \mathrm{PV}$ system over the same time interval as well as PV system costs and electricity tariffs were used to determine FITs needed to make it worthwhile for the households to invest in the PV system.

The proposed methodology shows that it is possible to design and compare the efficiencies of a number of different FIT structures for a population. Single and multiple FITs resulted in differing levels of overcompensation to householders in Ireland. As the number of FITs increase, efficiency increases with optimal efficiency being achieved when they equal the number of households adopting the technology. Continuous FITs are therefore the most efficient since they are designed for each household and result in no overcompensation. Single and 
multiple FITs are less efficient since they result in different levels of overcompensation to the households. In the PV case study considered, it was shown that the use of three FITs $(0.3170,0.3315$ and $0.3475 € / \mathrm{kWh})$ resulted in a $59.6 \%$ reduction in overcompensation compared to a single FIT of $0.3475 € / \mathrm{kWh}$; assuming immediate and complete uptake of the technology by $75 \%$ of households, this would result in NPV savings of over $€ 597 \mathrm{~m}$ to the Irish government over a 25 year lifetime.

Directive (2009/72/EC) commits member states to provide $80 \%$ of customers with smart meters by 2020 subject to a positive economic assessment of all the long-term costs and benefits. The economic benefits of multiple FITs demonstrated in this paper should be considered in these assessments.

\section{Acknowledgements}

We wish to express our profound appreciation to the Higher Education Authority of Ireland for financial support through the Arnold F. Graves and Strand III scholarship grants. We are also grateful to Electric Ireland for the data smart metering data.

\section{References}

Ayompe, L.M., Duffy, A., McCormack, S.J., Conlon, M., 2010. Validated real-time energy models for small-scale grid-connected PV-systems. Energy 35(10), 4086-4091.

Ayompe, L.M., Duffy, A., McCormack, S.J., Conlon, M., 2011. Measured performance of a $1.72 \mathrm{~kW}_{\mathrm{p}}$ rooftop grid connected photovoltaic system in Ireland. Energy Conversion and Management 52(2), 816-825.

Bhandari, R., Stadler, I., 2009. Grid parity analysis of solar photovoltaic systems in Germany using experience curves. Solar Energy 83(9), 1634-1644.

Brockington, R.B., 1993. Financial management. DP Publications Ltd.

Candelise, C., Gross, R., Leach, M.A., 2010. Conditions for photovoltiacs deployment in the UK: the role of policy and technical development. Journal of Power and Energy 224(2), 153-168. 
Central Statistics Office, 2012. <http://www.cso.ie>.

David, T., 2007. Renewable financial support systems and cost-effectiveness. Journal of Cleaner Production 15(3), 280-287.

Department of Energy and Climate Change, 2010. National renewable energy action plan for the United Kingdom. <http://www.decc.gov.uk>.

Electric Ireland and SEAI, 2012. Electricity smart metering data. <http:// www.ucd.ie/issda/>.

Enkvist, P., Nauclér, T., Rosander, J., 2007. A cost curve for greenhouse gas reduction. The McKinsey Quarterly: 35-45.

EPIA, 2010. PV observatory: Policy recommendations. < http://www.epia.org/policy/pv-observatory-sustainable-pv-policy.html>.

Eurobserv'er, 2009. Photovoltaic barometer. <http://www.eurobserv-er.org/pdf/baro202.pdf>

European Commission. (2012). Eurostat. <http://epp.eurostat.ec.europa.eu/portal/page/portal/energy/data/database>.

Heuston, D.A., 1983. Implicit discount rates and the purchase of untried, energy-saving durable goods. Journal of Consumer Research 10(2), 236-246.

Huld, T., Friesen, G., Skoczek, A., Kenny, R.P., Sample, T., Field, M., Dunlop, E.D., 2011. A powerrating model for crystalline silicon PV modules. Solar Energy Materials and Solar Cells 95(12), 3359-3369.

Kesicki, F., Strachan, N., 2011. Marginal abatement cost (MAC) curves: confronting theory and practice. Environmental Science and Policy 14(8), 1195-1204.

Lesser, J.A. and Su, X., 2008. Design of an economically efficient feed-in tariff structure for renewable energy development. Energy Policy 36(3), 981-990.

McHenry, M.P., 2012. A technical, economic, and greenhouse gas emission analysis of a homesteadscale grid-connected and stand-alone photovoltaic and diesel systems, against electricity network extension. Renewable Energy 38(1), 126-135.

Menanteau, P., Finon, D., Lamy, M.L., 2003. Prices versus quantities: choosing policies for promoting the development of renewable energy. Energy Policy 31(8), 799-812.

Mitchell, C., Bauknecht, D., Connor, P.M., 2006. Effectiveness through risk reduction: a comparison of the renewable obligation in England and Wales and the feed-in system in Germany. Energy Policy 34(3), 297-305.

Marques de Sá, J.P., 2007. Applied statistics using SPSS, Statistica, Matlab and R. Second Edition, Springer, New York.

Mondol, J.D., Yohanis, Y.G., Brian, N., 2007. Comparison of measured and predicted long term performance of grid a connected photovoltaic system. Energy Conversion and Management 48(4), 1065-1080.

Nfah, E.M., 2013. Evaluation of optimal photovoltaic hybrid systems for remote villages in Far North Cameroon. Renewable Energy 51, 482-488.

OFGEM, 2012. Feed-in tariff installation report $31^{\text {st }}$ December 2012. <http://www.ofgem.gov.uk>. 
Osterwald, C.R., Anderberg, A., Rummel, S., Ottoson, L., 2002. Degradation analysis of weathered crystalline-silicon PV modules. $29^{\text {th }}$ IEEE PV Specialists Conference, May 20-24, New Orleans, Louisiana, USA.

Paul, P., 2008. Residential solar photovoltaic market stimulation: Japanese and Australian lessons for Canada. Renewable and Sustainable Energy Reviews 12(7), 1944-1958.

Photovoltaic Power Systems Programme, 2008. Trends in photovoltaic applications: survey report of selected IEA countries between 1992 and 2007, (IEA-PVPS T1-17).

Poponi, D., 2003. Analysis of diffusion paths for photovoltaic technology based on experience curves. Solar Energy 74(4), 331-340.

Power, T., Walsh, S., O’Meara, P., 2009. Financial management: an Irish context. Gill \& Macmillan, Dublin.

Watson, J., Sauter, R., Bahaj, B., James, P.A., Myers, L., Wing, R., 2006. Unlocking the power house: policy and system change for domestic micro-generation in the UK, University of Sussex, University of Southampton, and Imperial College London. 